\title{
MORALNA WYMOWA GESTU NAMASZCZENIA STÓP I GŁOWY JEZUSA W QUAESTIO DE MARIA MAGDALENA ET MARIA SORORE LAZARI ET MARTHAE JOACHIMA Z FIORE
}

Postać Joachima z Fiore (ok. 1135-1202) - kalabryjskiego egzegety i mistyka, autora znanych w średniowieczu i późniejszych epokach dzieł, takich jak: Zgodność Starego i Nowego Testamentu (Concordia Novi ac Veteris Testamenti), Wyktad Apokalipsy (Expositio in Apocalypsim) i Dziesięciostrunne psalterium (Psalterium decem cordarum) - kojarzymy zwykle z pełną rozmachu wizją dziejów, zakorzenioną w Bogu jako Trójcy Osób oraz świetlaną epoką Ducha Świętego, poprzedzającą koniec dziejów i Sąd Ostateczny¹. Nie

* Ks. dr hab. Jan Grzeszczak, prof. UAM - profesor nadzwyczajny w Zakładzie Filozofii Chrześcijańskiej na Wydziale Teologicznym Uniwersytetu im. Adama Mickiewicza w Poznaniu; e-mail: xjangrze@amu.edu.pl.

${ }^{1}$ Literatura na temat Joachima z Fiore i jego wizji dziejów jest ogromna, a w ostatnich dziesięcioleciach nabrał również tempa proces udostępnienia czytelnikowi jego obszernej spuścizny dzięki skoordynowanym wysiłkom włoskich i niemieckich instytucji badawczych, takich jak: Centro internazionale di Studi Gioachimiti, L'Istituto Storico Italiano per il Medio Evo i Monumenta Germaniae Historica. Najbardziej reprezentatywne opracowania na temat Joachima z Fiore i joachimizmu: H. Grundmann, Studien über Joachim von Floris, Leipzig - Berlin 1927; B. McGinn, The Calabrian Abbot. Joachim of Fiore in the History of Western Thought, New York 1985; M. Reeves, The Influence of Prophecy in the Later Middle Ages. A Study in Joachimism, Notre Dame - London 1993; G.L. Potestà, Il tempo dell'Apocalisse. Vita di Gioacchino da Fiore, Bari 2004. Opracowania w języku polskim: J. Zbiciak, Joachim z Fiore, EK VIII 28-29; J. Grzeszczak, Joachim z Fiore. Średniowieczny przyczynek do teologii dziejów, Poznań 2006; tenże, Chwila jest bliska. Wizje końca w literaturze profetycznej (XIIXX wiek), Poznań 2011; tenże, Joachim z Fiore i filozofia dziejów, w: Przewodnik po filozofii średniowiecznej. Od św. Augustyna do Joachima z Fiore, red. A. Kijewska, Kraków 2012, 341358. Wybrane dzieła Joachima z Fiore przetłumaczone na język polski: Joachim z Fiore, Księga zgodności Starego i Nowego Testamentu (fragmenty), thum. P. Grad, „Kronos. Metafizyka, kultura, religia" 29 (2014) nr 2, 36-41; tenże, Wprowadzenie do Apokalipsy, tłum. P. Grad, tamże, 42-55; tenże, Wykład Apokalipsy (fragmenty), tłum. D. Nowakowski, tamże, 56-60; tenże, Psalterium o dziesięciu strunach (fragmenty), tłum. M. Beściak, tamże, 61-73; tenże, O siedmiu pieczęciach, tłum. A. Serafin, tamże, 74-77; tenże, List do Wielebnego Opata z Valdony, tłum. M. Beściak - D. Budzanowska, tamże, 78-80; tenże, List do wszystkich wiernych, tłum. M. Beściak - D. Budzanowska, tamże, 81-85. 
należy jednak zapominać, że ten popularny również dzisiaj autor jest także głęboko osadzony w średniowiecznej kulturze monastycznej, interesują go złożone procesy, którym podlegało ówczesne życie zakonne, zwłaszcza benedyktyńskie ${ }^{2}$. Wystarczy przywołać w tym miejscu Joachimowy Tractatus in expositionem vite et regule beati Benedicti - rodzaj apokaliptycznego i liturgicznego komentarza do żywota św. Benedykta, spisanego przez św. Grzegorza Wielkiego i zawartego w drugiej księdze Dialogów o cudach ojców italskich, w którym kalabryjski opat ukazał swoją eschatologiczną wizję dziejów życia monastycznego ze szczególnym podkreśleniem wyzwań, przed jakimi stanęło ono w XII wieku ${ }^{3}$. Już w młodości Joachim z Fiore związał się z obecnym na terenie ówczesnej Italii zakonem cysterskim, wstępując do kalabryjskiego klasztoru Santa Maria della Sambucina, skąd przeniósł się do ubogiej wspólnoty w Corazzo, stając na jej czele. W 2. poł. lat osiemdziesiątych XII w. opuścił jednak i ten dom, podejmując eremickie życie w górach Sila. Nie ulega

${ }^{2}$ Teologia dziejów Joachima z Fiore jest głęboko osadzona w dogmacie trynitarnym. Ten ostatni jest dla niej punktem wyjścia, natomiast postępująca spirytualizacja dziejów, której punktem kulminacyjnym ma być tertius status, czyli epoka Ducha Świętego, widoczna jest już w Starym Testamencie, będącym epoką Ojca. Jej obecność w pierwszej epoce dziejów (Duch Święty pochodzi od Ojca) jest dziejową konsekwencją dogmatu trynitarnego, w myśl którego Bóg jako Trójca Osób działa od początku historii zbawienia. Podobnie jest w drugiej epoce (Duch Święty pochodzi od Syna), w której św. Benedykt, inicjator życia monastycznego na Zachodzie, urasta do rangi autentycznego herolda nadchodzącej epoki Ducha Świętego. Pojawienie się i działalność mnichów są u Joachima z Fiore momentem dziejowego procesu rozwoju ordo monachorum, którego początek przypada na czasy proroka Elizeusza, a więc już w Starym Testamencie, a pełny rozkwit w czasach św. Benedykta. Wskazanie na te postacie wynika ze skomplikowanych, a często wręcz karkołomnych wyliczeń pokoleń, prowadzonych przez opata z Fiore w jego Zgodności Starego i Nowego Testamentu (Concordia Novi ac Veteris Testamenti). W rezultacie mamy w przypadku Joachima do czynienia z wizją dziejów niezwykle złożoną, w której trzy epoki dziejów przenikają się nawzajem. Jej autor jawi się na każdym etapie swojej refleksji jako teolog zatroskany o absolutną wierność trynitarnej doktrynie wyznawanej przez Kościół. Unika w ten sposób trudności, przed którymi stanęli jego średniowieczni kontynuatorzy. Upraszczając Joachimową wizję i sprowadzając ją tylko do trzech chronologicznie następujących po sobie epok, stanęli wobec poważnych problemów doktrynalnych, co widać choćby na przykładzie XIV-wiecznego dzieła, znanego jako Summula seu Breviloquium super Concordia Novi ac Veteris Testamenti, powstałego w kręgu ówczesnego radykalnego franciszkanizmu. Por. Western Mediterranean Prophecy. The School of Joachim of Fiore and the Fourteenth-Century Breviloquium, ed. H. Lee - M. Reeves - G. Silano, Toronto 1989, 164-322; J. Grzeszczak, Późnośredniowieczne dziedzictwo Joachima z Fiore: Summula seu Breviloquium super Concordia Novi ac Veteris Testamenti, w: Deum et animam scire. Teksty filozoficzne dedykowane księdzu arcybiskupowi profesorowi Markowi Jędraszewskiemu, red. J. Grzeszczak - K. Stachewicz, Poznań 2015, 366-367.

${ }^{3}$ Por. Ioachim abbas Florensis, Tractatus in expositionem vite et regule beati Benedicti cum appendice fragmenti (I) de duobus prophetis in novissimis diebus praedicaturis, ed. A. Patschovsky, Fonti per la storia dell'Italia medievale, Antiquitates 29, Roma 2008; Gregorius Magnus, Dialogi II, éd. A De Vogüé, SCh 260, Paris 1979, 126-249, tłum. E. Czerny - A. Świderkówna: Św. Grzegorz Wielki, Dialogi, ŹM 23, Kraków - Tyniec 2007, 137-201. 
wątpliwości, że Tractatus stanowił próbę usprawiedliwienia tej samowolnej bądź co bądź decyzji opuszczenia cysterskiej rodziny ${ }^{4}$.

Podjętą przez Joachima decyzję należy widzieć w kontekście jego apokaliptyki, dla której punktem wyjścia było zarówno intensywne studium Biblii, jak i uważna lektura wydarzeń, jakie miały miejsce w 2. poł. XII w. Opat z Fiore stopniowo nabrał przekonania, że gorliwość kluniacka, która w przeszłości przyczyniła się do odrodzenia średniowiecznego Kościoła, ustapiła miejsca bezduszności oraz zamiłowaniu do bogactwa i wygodnego życia, co skutkowało egoizmem, widocznym w funkcjonowaniu poszczególnych domów benedyktyńskich, zanikiem poczucia więzi i postępującym formalizmem ${ }^{5}$. Reakcją na upadek życia zakonnego w wydaniu kluniackim było z pewnością pojawienie się cystersów ${ }^{6}$. Pomijając $\mathrm{w}$ tym miejscu złożony problem Joachimowej egzegezy, na której opiera się wizja opata, należy stwierdzić, że model cysterski nie jest ostatnim słowem w jego wizji dziejów życia zakonnego ${ }^{7}$. Cystersi - zdaniem Joachima z Fiore - nie będą w stanie stawić czoła nadchodzącej apokalipsie z powodu wewnętrznych sprzeczności, widocznych w ich sposobie życia. Widoczny w czasach opata dynamiczny rozwój cysterskich klasztorów, a co za tym idzie rozrost zadań organizacyjnych, utrudnił realizację właściwej cystersom misji, jaką była kontemplacja ${ }^{8}$.

${ }^{4}$ Por. C.D. Fonseca, Gioacchino da Fiore tra riforma del monachesimo e attesa della fine, w: Gioacchino da Fiore tra Bernardo di Clairvaux e Innocenzo III. Atti del $5^{\circ}$ Congresso internazionale di studi gioachimiti, San Giovanni in Fiore - 16-21 settembre 1999, a cura di R. Rusconi, Opere di Gioacchino da Fiore: testi e strumenti 13, Roma 2001, 14.

${ }^{5}$ Wskazując na relację pomiędzy Izaakiem i jego synem Ezawem, Joachim z Fiore piętnuje sposób działania benedyktyńskich opatów. Zob. Ioachim abbas Florensis, Tractatus I 3, ed. Patschovsky, s. 134: „Quodsi ita est, quomodo quidam abbates nolunt putari patres, sed domini, nolunt amari, sed timeri, parvipendentes illud quod scriptum est: Timor non est in caritate, sed perfecta caritas foras mittit timorem? Diligunt ergo illos, quorum venationibus pascuntur, predicantes eis virtutem obedientie, quasi non melius sit in libertate spiritus studere paupertati quam quasi occasione obedientie cupiditati consulere, aut non magis sit a monacho interior obedientia exigenda quam exterior, et fructus iustitie quam tesauri”. Por. 1J 4, 18; Rdz 27, 3-4; Flp 1, 11; Jk 3, 18.

${ }^{6}$ Por. tamże II 2B, ed. Patschovsky, s. 170-171: „Completum est anno $\mathrm{M}^{\circ} \mathrm{XC}^{\circ}$ sexto incarnationis dominice, quando novus ille ac pius grex, qui egressus est de Molismo, mansurus secum Domino venit Cistercium, inchoaturus cisterciensem ordinem, in quo vivit et proficit Benedictus". Pojawienie się cystersów zostało zestawione przez Joachima z odejściem św. Benedykta z klasztoru w Vicovaro po tym jak tamtejsi mnisi, nie chcąc poddać się wymaganiom reguły, chcieli otruć opata. Św. Benedykt powrócił wtedy do swojej ukochanej samotni i ,sam pod okiem najwyższego Świadka mieszkał ze sobą (solus in superni spectatoris oculis habitauit secum)". Widoczne w Joachimowym tekście wyrażenie secum Domino stanowi - zdaniem A. Patschovskiego - wyraźną aluzję do postawy Marii, siostry Marty z Łk 10, 39 (sedens secus pedes Domini). Zob. Ioachim abbas Florensis, Tractatus, ed. Patschovsky, s. 170, nota 103. Por. Gregorius Magnus, Dialogi II 3, 5, SCh 260, 142, ŹM 23, 146.

${ }^{7} \mathrm{Na}$ temat Joachimowej egzegezy biblijnej i jej wpływie na wizję dziejów życia zakonnego w średniowieczu zob. Grzeszczak, Chwila jest bliska, s. 67-84.

${ }^{8}$ Por. Ioachim abbas Florensis, Tractatus II 3, ed. Patschovsky, s. 177: „Est enim montis vertex artior quidem, sed altior, quia vita pauperior paucos tolerat, sed tamen ad contemplandum oportu- 
W ciekawy sposób Joachim z Fiore interpretuje znany epizod z życia św. Benedykta, który co roku schodził na spotkanie ze swoją siostrą św. Scholastyką9. Ta ostatnia, symbolizująca w wizji Joachima zakon cystersów, choć święta i czysta, to jednak jako słaba kobieta nie jest w stanie wspiąć się na strome szczyty kontemplacji i stąd decyzja jej brata, by co roku schodzić do niej i rozmawiać w budynku należącym do klasztoru ${ }^{10}$. Zejście św. Benedykta na spotkanie siostry nabiera u Joachima z Fiore wręcz symbolicznego wymiaru i staje się swego rodzaju metaforą relacji pomiędzy mnichami, którzy poczynili postępy na drodze wiodącej ku kontemplacji, i ich współbraćmi wymagającymi troski. Wolno pozostać tym pierwszym na wyżynach kontemplacji, nie wypada im jednak pozostawić bez pomocy tych, którzy jej potrzebuja (por. 1Kor 6,12). W De articulis fidei - traktacie na temat chrześcijańskiego Credo, dedykowanym swoim współbraciom - Joachim z Fiore powraca do tego zagadnienia, czerpiąc inspirację z wyznania św. Pawła z listu do Filipian: „Nie mam bowiem nikogo o równych dążeniach ducha, który by się szczerze zatroszczył o wasze sprawy: bo wszyscy szukają własnego pożytku, a nie Chrystusa Jezusa" 11 .

Jak zauważa Cosimo D. Fonseca, tym, co uniemożliwia cystersom osiągnięcie pełni kontemplacji, właściwej przedstawicielom ostatniej epoki dziejów, jest nie tylko brak praktyki całkowitego ubóstwa w wymiarze indywidualnym, jak i wspólnotowym, lecz również konieczne skądinąd pomieszanie życia aktywnego i kontemplacyjnego ${ }^{12}$.

Po przeanalizowaniu dziejów benedyktynów i cystersów, opat z Fiore postuluje „trzecią przemianę” (tertia mutatio), czyli powołanie do życia nowej rodziny zakonnej, swoją surowością życia w górach nawiązującą do tradycji

nior est. Crescente etenim fratrum numero, crescant protinus curarum crines, crescant sollicitudinum pili et negotiorum cesaries. Non igitur in arto montis manere potest, qui inferius dilatatur et crescit, nec videre potest alta consilia, qui circa rerum minima occupatus tabescit".

${ }^{9}$ Por. Gregorius Magnus, Dialogi II 33, 1-5, SCh 260, 231-235, ŹM 23, 190-193.

${ }^{10}$ Por. Ioachim abbas Florensis, Tractatus II 3, ed. Patschovsky, s. 180-181: „Igitur in beata Scolastica Cisterciensium unanimitas designatur, que licet sancta et innocens, ut imbecilis tamen femina ardua montis scandere et tam arta nequivit. Non solum autem, sed et vir Domini Benedictus ad eam descendere caritate compulsus est, quia hi, qui possent in ordine in alto stare, et iam stare incipient, compellentur propter infirmos fratres aliquantulum a rigore suo flecti et ad eos, qui infra sunt, condescendere, et vincente caritate humilium etiam pernoctare cum illis compellentur inviti".

${ }^{11}$ Por. tenże, De articulis fidei ad fratrem Iohannem 15, ed. V. De Fraja, w: tenże, De articulis fidei ad fratrem Iohannem. Confessio fidei, Fonti per la storia dell'Italia medievale, Antiquitates 37, Roma 2012, 42: „Quia solos probatos viros et perfectos dignos iudicavimus sancto otio, dicentes non debere cogi esse sub humana lege qui spiritu ducuntur divino, queritur non absurde utrum semper eis ipis, qui perfecti sunt, expediat omne quod licet, an oporteat aliquando eos quoque condescendere infirmis fratribus, ut videatur non sua magis querere, set que Iesu Christi. Quod enim non expediat viris perfectis omnia que licent, testatur manifeste apostolus qui dicit: Omnia michi licent, set non omnia expediunt. Et quod debeant aliquando coinfirmari infirmis, et verbo idem ipse testatus est dicens: Factus sum infirmis infirmus ut infirmos lucrarer". Zob. Flp 2, 21; 1Kor 9, 22.

${ }^{12}$ Por. Fonseca, Gioacchino da Fiore, s. 18-19. 
eremickiej i w ten sposób wychodzącą naprzeciw nadchodzącej apokalipsie: „Gdy więc ujrzycie «ohydę spustoszenia», o której mówi prorok Daniel, zalegającą miejsce święte [...] wtedy ci, którzy będą w Judei, niech uciekaja w góry" (Mt 24, 15; por. Dn 9, 27). Wydaje się, że Joachim zinterpretował dosłownie ten fragment Mateuszowej Ewangelii o znakach zapowiadających powtórne przyjście Zbawiciela.

„Spodobało mu się więc udać w górską okolicę Sila i szukać w tych zimnych

górach miejsca, w którym mogliby w jakiś sposób zamieszkać"13

- stwierdza anonimowy biograf Joachima z Fiore z początku XIII w. XII-wieczne europejskie herezje $\mathrm{w}$ sojuszu $\mathrm{z}$ ówczesnym wojującym islamem stanowią dla opata z Fiore przerażający scenariusz bliskiej przyszłości, wypełnienie apokaliptycznego proroctwa o „Bestii wychodzącej z morza” i „Bestii wychodzącej z ziemi” (por. Ap 13).

Należy jednak podkreślić, że dla Joachima z Fiore te przywołane wyżej nieuchronne procesy o charakterze globalnym nie eliminują wolności jednostki, która stanowi tak istotny wyznacznik chrześcijańskiego spojrzenia na osobę. Nie jest mu również obca wielka tematyka usprawiedliwienia, widoczna w listach św. Pawła, a także osadzone głęboko w średniowiecznej duchowości monastycznej przekonanie o prymacie cnoty pokory. Dla Joachima z Fiore oryginalnie ujęta dialektyka pychy i pokory staje się motorem dziejowych procesów, czego przykład znajdziemy choćby w niewielkim traktacie jego autorstwa, znanym jako Intelligentia super calathis i będącym próbą egzegezy wizji dwóch koszów fig z 24 rozdziału proroctwa Jeremiasza ${ }^{14}$. Zagadnienia te, pojawiające się w przywołanych wyżej dziełach, ukazują opata z Fiore jako autora zatroskanego o zakonną formację swoich podopiecznych i podejmującego problemy pojawiające się w praktyce ówczesnego życia monastycznego. Często pojawiającym się punktem odniesienia jest w nich oryginalna teologia dziejów, będąca najbardziej znanym elementem spuścizny tego średniowiecznego autora.

1. Problematyka dzieła. Bogatsi o te, siłą rzeczy, skrótowe informacje na temat problematyki pojawiającej się w Joachimowej spuściźnie, przystępuje-

${ }^{13}$ Vita beati Joachimi abbatis, ed. S. Oliverio, „Florensia” 16-17 (2002-2003) 226, thum. własne.

${ }^{14} \mathrm{Na}$ temat Joachimowej egzegezy Jr 24 zob. Ioachim abbas Florensis, Intelligentia super calathis ad abbatem Gafridum, w: tenże, Scripta breviora, ed. A. Patschovsky - G.L. Potestà, Fonti per la storia dell'Italia medievale, Antiquitates 40, Roma 2014, 185-217; P. De Leo, Gioacchino da Fiore. Aspetti inediti della vita e delle opere, Soveria Mannelli 1988, 135-148; H. Grundmann, Kirchenfreiheit und Kaisermacht um 1190 in der Sicht Joachims von Fiore, „Deutsches Archiv für Erforschung des Mittelalters" 19 (1963) 353-396; tenże, Ausgewählte Aufsätze, teil 2: Joachim von Fiore, MGH, Schriften 25/2, Stuttgart 1977, 361-402; J. Grzeszczak, Two Diagrams Rome and Babylon and Their Doctrinal and Moral Message, „Annali di scienze religiose” 5 (2012) 141-170; tenże, Głos teologa w sprawach średniowiecznej polityki. Diagramy Roma i Babilonia oraz ich wymowa doktrynalna i moralna, „Kronos. Metafizyka, kultura, religia” 29 (2014) nr 2, 122-140. 
my do analizy dzieła, które pojawia się w tytule tego artykułu. W 2014 r. ukazał się staraniem rzymskiego L'Istituto Storico Italiano per il Medio Evo i Centro internazionale di Studi Gioachimiti z siedzibą w kalabryjskim San Giovanni in Fiore zbiór sześciu mniejszych objętościowo dzieł tego średniowiecznego autora oraz jego listy i poematy ${ }^{15}$. Inicjatywa dwóch włoskich ośrodków mediewistycznych stanowi znaczący krok w kierunku udostępnienia naukowcom całej spuścizny Joachima z Fiore. Scripta breviora Joachima z Fiore zawierają również niewielką objętościowo Quaestio de Maria Magdalena et Maria sorore Lazari et Marthae ${ }^{16}$. Ten interesujący traktat, poświęcony postaciom kobiet występujących w Ewangelii, dotrwał do naszych czasów w jedynym rękopisie, wchodzącym w skład XIII-wiecznego kodeksu, będącego rodzajem antologii dzieł Joachima z Fiore, opatrzonego sygnaturą 322 i przechowywanego w padewskiej Biblioteca Antoniana. Kodeks ten, jak dowiodły badania prowadzone w latach osiemdziesiątych ubiegłego wieku, ujrzał światło dzienne w 1. poł. XIII w. w cysterskim opactwie Santa Maria della Sambucina w Kalabrii i zajmuje ważne miejsce $\mathrm{w}$ procesie upowszechniania pism opata z Fiore na terenie średniowiecznej Italii ${ }^{17}$.

Quaestio de Maria Magdalena doczekała się, jak dotąd, trzech wydań drukiem. Oprócz wspomnianej wyżej niedawnej edycji w ramach Scripta brevio$r a$ Joachima z Fiore, przygotowanej przez znakomitego niemieckiego mediewistę Alexandra Patschovskiego, pod koniec ubiegłego wieku ukazały się we Włoszech dwie edycje tego traktatu ${ }^{18}$. Dzieło, liczące w edycji A. Patschovskiego nieco ponad piętnaście stron, dzieli się na dwie części: w pierwszej z nich Joachim dokonuje przeglądu fragmentów Ewangelii, w których mowa o kobietach namaszczających Jezusa olejkiem. Ewangeliści przekazują że gestu tego Jezus doświadczył dwa razy. Z przekazu św. Łukasza dowiadujemy się, że po raz pierwszy miało to miejsce w Galilei po wskrzeszeniu przez Jezusa młodzieńca z Nain i poselstwie od Jana Chrzciciela, podczas uczty u faryzeusza o imieniu Szymon (por. Łk 7, 36-50): „A oto kobieta, która prowadziła

${ }^{15}$ Zob. Ioachim abbas Florensis, Scripta breviora. W skład tej edycji mniejszych dzieł Joachima z Fiore, wydanej w tomie 40 serii Fonti per la storia dell'Italia medievale, Antiquitates, wchodzą traktaty: Genealogia sanctorum antiquorum patrum, De prophetia ignota, Soliloquium, Intelligentia super calathis ad abbatem Gafridum, Quaestio de Maria Magdalena et Maria sorore Lazari et Marthae, De ultimis tribulationibus, a także Epistolae (Epistola ad abbatem A. Veldonensis monasterii, Epistola Universis Christi fidelibus, Epistola testamentaria), Poemata duo (Visio admirandae historiae, Hymnus de regno patriae supernae) oraz Epistola Clementis III papae ad Ioachimum abbatem de Curatio. Dwa listy Joachima z Fiore (Epistola ad abbatem A. Veldonensis monasterii, Epistola Universis Christi fidelibus) dostępne są w tłumaczeniu na język polski - por. nota 1.

${ }^{16}$ Por. Ioachim abbas Florensis, Quaestio de Maria Magdalena et Maria sorore Lazari et Marthae, ed. A. Patschovsky - G.L. Potestà, w: tenże, Scripta breviora, s. 245-260.

${ }^{17} \mathrm{Na}$ temat rękopisu padewskiego zob. V. De Fraja, Un'antologia gioachimita: il manoscritto 322 della Biblioteca Antoniana di Padova, SM 32 (1991) nr 1, 231-250.

${ }^{18}$ Por. De Leo, Gioacchino da Fiore. Aspetti inediti della vita e delle opere, s. 157-163; De Fraja, Un'antologia gioachimita, s. 251-258. 
w mieście życie grzeszne, dowiedziawszy się, że jest gościem w domu faryzeusza, przyniosła flakonik alabastrowy olejku, i stanąwszy z tyłu u nóg Jego, płacząc zaczęła łzami oblewać Jego nogi i włosami swej głowy je wycierać. Potem całowała Jego stopy i namaszczała je olejkiem” (Łk 7, 37-38).

Po raz drugi Jezus został namaszczony w Judei, w Betanii, o czym wspominają Mateusz, Marek i Jan (por. Mt 26, 6-13; Mk 14, 3-9; J 12, 1-8). Te wzruszające i pełne teologicznej wymowy gesty były dziełem kobiet. Ich tożsamość była w okresie patrystycznym przedmiotem dyskusji, do których nawiązuje również nasz autor:

„Tamta więc była grzesznicą, ta zaś, według Ambrożego - dziewicą, chociaż różni różnie do tego podchodzą i inni inaczej się na to zapatrują"19.

Opat z Fiore odwołuje się w tym miejscu do komentarza do Ewangelii według św. Łukasza autorstwa św. Ambrożego, w którym biskup Mediolanu interpretuje gest wylania przez kobietę drogiego olejku na głowę Jezusa podczas uczty u Szymona Trędowatego w Betanii jako przejaw jej sprawiedliwości i wynikającego z niej przekonania, że miała prawo tak uczynić. Owa kobieta ukazana jest przez Ambrożego jako ta, która nabożnie służy wcielonemu Słowu Boga, pokładając ufność w swojej nieskalanej czystości ${ }^{20}$.

Stopniowo wyłania się w ten sposób problem, który Joachim z Fiore chce rozwiązać w analizowanym przez nas traktacie. Jak pogodzić ze sobą odległą na pierwszy rzut oka symbolikę biblijnej postaci nawróconej grzesznicy z Galilei z tym, co w tradycji Kościoła ucieleśnia siostra Marty Maria, która „siadła u nóg Pana i przysłuchiwała się Jego mowie” (Łk 10, 39)21? Opat wy-

${ }^{19}$ Ioachim abbas Florensis, Quaestio de Maria Magdalena et Maria sorore Lazari et Marthae I 1, ed. Patschovsky - Potestà, s. 246: „Illa ergo peccatrix fuit, hec secundum Ambrosium virgo, licet diversi diversa sentiant et alii aliud opinentur", tłum. własne.

${ }^{20}$ Por. Ambrosius Mediolanensis, Expositio Evangelii secundum Lucam libris X comprehensa 6, 14, PL 15, 1672: „Hanc ergo mulierem inducit sanctus Matthaeus supra caput Christi effundentem unguentum (Mt 26, 7): et ideo forte noluit dicere peccatricem, nam peccatrix secundum Lucam supra Christi pedes effudit unguentum. Potest ergo non eadem esse, ne sibi contrarium evangelistae dixisse videantur. Potest etiam quaestio meriti et temporis diversitate dissolvi, ut adhuc illa peccatrix sit, jam ista perfectior. Etsi enim personam non mutet Ecclesia, vel anima; tamen mutat profectum. Itaque si constitutas animam fideliter appropinquantem Deo, non peccatis turpibus et obscoenis, sed pie servientem Dei Verbo, habentem immaculatae fiduciam castitatis, advertis quod ad ipsum Christi ascendit caput et odorem meritorum spargit suorum: Christi enim bonus odor sumus Deo. Deus quippe honorat bonum fragrans odorem vita justorum". Zob. Ioachim abbas Florensis, Quaestio de Maria Magdalena et Maria sorore Lazari et Marthae, ed. Patschovsky - Potestà, s. 246, nota 6.

${ }^{21}$ A. Patschovsky (Einleitung, w: Ioachim abbas Florensis, Scripta breviora, s. 222) uważa, że rozwiązanie zarysowanego w ten sposób problemu było celem, jaki Joachim z Fiore postawił sobie, przystępując do pracy nad swoim dziełem: „Wie aber vertrug sich die Symbolfigur der bekehrten Sünderin mit der Protagonistin mönchisch-kontemplativer Lebensweise, wie się Maria von Bethanien verkörperte, die - der Tradition nach Jungfrau - zu Jesu Füßen dessen Worten gelauscht hatte im Unterschied zu ihrer Schwester Martha, die eher um das leibliche Wohl Jesu besorgt gewesen und damit zum Urbild der vita activa geworden war? Hier lag Joachims Problem". 
chodzi w swoim rozumowaniu od przesłanki, którą stanowi wyraźne odróżnienie dwóch krain, dwóch miast i dwóch kobiet (Ecce autem habemus duas provincias, duo loca, duas mulieres): Galilei i Judei, Nain i Betanii, grzesznicy namaszczającej stopy Jezusa i kobiety, która wylała Mu olejek na głowę, gdy spoczywał przy stole ${ }^{22}$. Celem jego wywodu jest odkrycie głębszego znaczenia tych dwóch gestów zapisanych na kartach Ewangelii. Dla Jezusa nie były one mało znaczaccym epizodem: „Zaprawdę, powiadam wam: Gdziekolwiek po całym świecie głosić będą tę Ewangelię, będą również opowiadać na jej pamiątkę to, co uczyniła" (Mt 26, 13; por. Mk 14, 9). Zarówno tutaj, jak i na początku traktatu, Joachim z Fiore wskazuje również metodę, którą zamierza się posłużyć w realizacji swojego przedsięwzięcia: ma zamiar odwołać się do słów samej Ewangelii (verbis evangelicis enodare, verbis evangelicis indagandum est $)^{23}$. Dotykamy w tym miejscu elementu, który decyduje o oryginalności myśli kalabryjskiego opata. Jawi się on w całej swojej refleksji jako niestrudzony badacz biblijnego przesłania, przekonany o tym, że Bóg udzielił mu specjalnego daru, jakim jest „duch zrozumienia” (spiritus intelligentiae) pism natchnionych ${ }^{24}$. Verba evangelica $\mathrm{z}$ interesującego nas traktatu przywodzą na myśl verba autentica - termin, który pojawia się w innym Joachimowym traktacie, De prophetia ignota, będącym próbą interpretacji tekstu krótkiej sybilli, znalezionej w bibliotece pozostałej w Rzymie po zmarłym w latach osiemdziesiątych XII w. kardynale Mateuszu z Angers ${ }^{25}$. Tam również kluczem do zrozumienia bardzo niejasnej w swej treści przepowiedni były verba autentica - słowa autentyczne, prawdziwe, pewne i godne zaufania, ponieważ należące do kanonu Pism natchnionych ${ }^{26}$.

W dalszym ciągu pierwszej części traktatu Joachim z Fiore dokonuje przeglądu fragmentów Ewangelii ukazujących słowa i znaki Jezusa w Galilei po to, aby w bardzo skrótowy sposób przejść do Jego działalności w Judei, u której początków, według św. Łukasza, zawitał do Marii i Marty ${ }^{27}$. Kalabryjski

${ }^{22}$ Por. Ioachim abbas Florensis, Quaestio de Maria Magdalena et Maria sorore Lazari et Marthae I 1, ed. Patschovsky - Potestà, s. 246.

${ }^{23}$ Por. tamże, ed. Patschovsky - Potestà, s. 247: „Quod tamen an ita fuerit an non ita, verbis evangelicis indagandum est”; tamże, ed. Patschovsky - Potestà, s. 245: „Usitatam inter plurimos questionem de Maria Magdalena et Maria, sorore Lazari et Marthe, volo, si possum, verbis evangelicis enodare, ne quis unam eademque extimet fuisse Mariam, eo quod non desint qui hoc putent usque ad presentem diem".

${ }^{24}$ Więcej na ten temat zob. Grzeszczak, Joachim z Fiore, s. 71-90.

${ }^{25}$ Por. Ioachim abbas Florensis, De prophetia ignota, ed. A. Patschovsky - G.L. Potestà, w: tenże, Scripta breviora, s. 55-90.

${ }^{26}$ Por. tamże, ed. Patschovsky - Potestà, s. 59, nota 10; M. Kaup, Introduzione, w: Gioacchino da Fiore, Commento a una profezia ignota, a cura di M. Kaup, Opere di Gioacchino da Fiore: testi e strumenti 10, Roma 1999, 85 i 107, nota 7; Grzeszczak, Chwila jest bliska, s. 45.

${ }^{27}$ Por. Ioachim abbas Florensis, Quaestio de Maria Magdalena et Maria sorore Lazari et Marthae I 2, ed. Patschovsky - Potestà, s. 249-250: „Que postquam gesta sunt [dokonane w Galilei - J.G.], abiit in Iudeam et intravit in Bethaniam castellum Marie et Marthe, et exinde cepit evan- 
opat wyciaga z analizy fragmentów biblijnych wniosek, który można uznać za rodzaj prowizorycznej konkluzji pierwszej części traktatu. Kobieta, która prowadziła w mieście życie grzeszne, staje się reprezentantką tych wszystkich, których dotknęła zbawiająca moc Chrystusa nauczającego i uzdrawiającego w Galilei. To, że jej ojczyzną była Galilea oraz fakt, że jej spotkanie z Jezusem miało miejsce na długo przed Jego męką i śmiercią, przemawia za tym, że nie można - zdaniem Joachima z Fiore - utożsamiać jej z kobietą, która namaściła głowę Zbawiciela w Betanii ${ }^{28}$. We właściwy sobie sposób kalabryjski opat stawia przed czytelnikiem trzy pary figur, które nabierają ostatecznie wymowy moralnej: dwie krainy (Galilea i Judea), dwa miasta (Nain i Betania) oraz dwie kobiety (grzesznica i dziewica). Tak więc na podstawie analizy fragmentów biblijnych można wyciaggnąć wniosek, że w Ewangelii mamy do czynienia ze stopniową przemianą relacji z Bogiem. Na początku grzesznica ma dostęp tylko do stóp Zbawiciela, później jednak, usprawiedliwiona, może sięgnąć do Jego głowy.

W drugiej części traktatu Joachim podejmuje zapowiedziany już na początku problem, dotyczacy Marii Magdaleny i Marii z Betanii, czy mamy w ich przypadku do czynienia z dwiema osobami czy z jedną (utrum due fuerint an $u n a)^{29}$. Od czasów św. Grzegorza Wielkiego przyjęło się w Kościele zachodnim utożsamianie Marii Magdaleny z siostrą Marty lub grzesznicą z Galilei, do czego walnie się przyczyniły dwie homilie (XXV i XXXIII), w których papież podjął temat spotkania Marii Magdaleny ze zmartwychwstałym Chrystusem (por. J 20, 11-18) oraz uczty u faryzeusza Szymona (por. Łk 7, 36-50) ${ }^{30}$. Joachim podkreśla jednak, że Ewangelia w sposób jednoznaczny stwierdza coś innego:

„To, że mamy do czynienia z dwiema kobietami, z których druga miała na imię Maria, w sposób jednoznaczny potwierdza autorytet Ewangelii. Albowiem Maria Magdalena pochodziła z Galilei, natomiast Maria, siostra Marty - z Betanii, miejscowości w Judei, która «była oddalona od Jerozolimy

gelizare et signa facere in regione Iudee”. Zob. Łk 10, 38-42. U pozostałych ewangelistów epizod z Betanii jest częścią opowiadania o Męce Jezusa.

${ }^{28}$ Por. tamże, ed. Patschovsky - Potestà, s. 250: „Et cum constet, quod in alia regione id acciderit quam in Iudea, et longe ante passionem, liquet, quod alia fuerit mulier illa que et peccatrix dicta est, alia illa que, cum esset in Bethania Dominus Iesus, uncxit unguento caput eius tempore passionis ipsius, ita ut diceret Dominus de ea: Quod habuit, hoc fecit. Prevenit ungere corpus meum in sepulturam". Zob. Mk 14, 8.

${ }^{29}$ Por. tamże.

${ }^{30}$ Por. Gregorius Magnus, XL homiliarum in Evangelia libri duo XXV 1, PL 76, 1189: „Maria Magdalene, quae fuerat in civitate peccatrix, amando veritatem, lavit lacrymis maculas criminis"; tamże XXXIII 1, PL 76, 1239: „Cogitanti mihi de Mariae poenitentia, flere magis libet quam aliquid dicere [...] Hanc vero quam Lucas peccatricem mulierem, Ioannes Mariam nominat, illam esse Mariam credimus de qua Marcus septem daemonia ejecta fuisse testatur". Zob. S. Szymik, Maria Magdalena, EK XI 1319. 
około piętnastu stadiów» (J 11, 18). O tym, że tak właśnie było, uczy jeden $\mathrm{i}$ ten sam Ewangelista" ${ }^{31}$.

Ewangelistą tym jest św. Łukasz, wymieniający Marię Magdalenę wśród kobiet, które Jezus „uwolnił od złych duchów i słabości”; te same kobiety z Galilei były świadkami złożenia Jego ciała do grobu, natomiast zestawienie fragmentów Łukasza z Mateuszem, Markiem i Janem pozwala stwierdzić, że Maria, siostra Marty i Łazarza, pochodziła z Betanii ${ }^{32}$.

Ostatnim problemem, jaki pozostał do rozwiązania w kwestii tożsamości kobiet występujących w Ewangelii, jest dla Joachima próba odpowiedzi na pytanie, czy Maria Magdalena rzeczywiście była grzesznicą z Galilei, jak sugeruje św. Grzegorz Wielki, i czy Maria, siostra Marty, jest kobietą z Ewangelii według św. Mateusza, która wylała Jezusowi na głowę olejek podczas uczty u Szymona Trędowatego ${ }^{33}$. Tego pierwszego - jak stwierdza Joachim -

„nie da się pewnie udowodnić, lecz zakładają to święci doktorzy, ponieważ jedno jest wzmiankowane blisko drugiego. W tym bowiem miejscu, gdzie mowa jest o kobiecie, «która prowadziła w mieście życie grzeszne» (Łk 7, 37), a której «odpuszczone zostały grzechy» (Łk 7, 47), natychmiast dodano: «następnie wędrował przez miasta i wsie, nauczając i głosząc Ewangelię o królestwie Bożym. A było z nim Dwunastu oraz kilka kobiet, które uwolnił od złych duchów i od słabości: Maria zwana Magdaleną, którą opuściło siedem złych duchów» (Łk 8, 1-2)"34.

W przywołanej wyżej homilii na temat spotkania Marii Magdaleny ze Zmartwychwstałym św. Grzegorz Wielki nawiązuje do słów Zbawiciela: „Odpuszczone są jej liczne grzechy, ponieważ bardzo umiłowała” (Łk 7, 47), i stwierdza: ,Ta, która wcześniej była oziębła, grzesząc, później mocno kochając, płonęła”" J5 . Jej „moc miłości” (vis amoris) sprawiła - powie papież - że płacząca Maria Magdalena pozostała przed grobem nawet wtedy, gdy Piotr i Jan powrócili już stamtąd do siebie ${ }^{36}$. Joachim z Fiore podąża tym tropem

${ }^{31}$ Ioachim abbas Florensis, Quaestio de Maria Magdalena et Maria sorore Lazari et Marthae II 1, ed. Patschovsky - Potestà, s. 251, tłum. własne.

${ }^{32}$ Por. tamże, ed. Patschovsky - Potestà, s. 251-252: „Sicut ergo de lectione evangelica aperte constat, quod Maria soror Lazari et Marthe fuit de Bethania castello Iudee, ita luce clarius liquet, quod Maria Magdalena, que prius fuerat Christum secuta, fuit de Galilea, et, ut quidam tradunt, de castello quod vocatur Magdalum prope litus maris Galilee, quo nomine vocatur locus ille usque in presentem diem". Zob. Łk 8, 1-3; 23, 55; 24, 10; Mt 26, 6-7; Mk 14,3; Łk 10, 38-42; J 12, 1-3.

${ }^{33}$ Por. tamże, ed. Patschovsky - Potestà, s. 252; Mt 26, 6-7. Zob. nota 19.

${ }^{34}$ Tamże, ed. Patschovsky - Potestà, s. 252-253, tłum. własne.

${ }^{35}$ Gregorius Magnus, XL homiliarum in Evangelia libri duo XXV 1, PL 76, 1189: „Quae enim prius frigida peccando remanserat, postmodum amando fortiter ardebat", thum. własne.

${ }^{36}$ Por. tamże: „Qua in re pensandum est hujus mulieris mentem quanta vis amoris accenderat, quae a monumento Domini, etiam discipulis recedentibus, non recedebat. Exquirebat quem non invenerat, flebat inquirendo, et amoris sui igne succensa, ejus quem oblatum credidit ardebat desiderio. Unde contigit ut eum sola tunc videret, quae remansit ut quaereret, quia nimirum virtus boni 
i rozszerzając swoją egzegetyczną perspektywę na inne postacie z Ewangelii, stwierdza, co następuje:

„Jak bowiem Piotr miłował bardziej niż Jan, tak też owa Maria wydaje się bardziej kochać niż Maria, siostra Marty, chociaż widzimy, że Jezus szczególnie miłował Marię, siostrę Marty, do tego stopnia, że rozrzewnił Go jej płacz, tak samo Jana, o którym mówi Pismo: ów uczeń, «którego Jezus miłował» (J 13, 23). Źródło bowiem tajemnicy (causa misterii) jedno jest w obydwu przypadkach"37.

Dotykamy w tym momencie głównych elementów Joachimowej typologii biblijnej $^{38}$. Sam opat z Fiore jest świadom, że dotknął w tym momencie problematyki, której poświęcił praktycznie całe swoje życie. Piotr i Marta wskazują na vita activa, natomiast Jan i Maria z Betanii na vita contemplativa. Ten fundamentalny motyw dwóch rodzajów aktywności przenika całą teologię dziejów Joachima z Fiore. Piotr odpowiedział na Chrystusowe wezwanie „Pójdź za mną” i realizował je w trudzie swojej pasterskiej posługi, podobnie jak rzesza biskupów Kościoła, którzy przyszli po nim.

We wprowadzeniu do obszernego Wykładu Apokalipsy (Expositio in Apocalypsim) Joachim nie tylko wiąże postać apostoła Piotra z życiem aktywnym, a Jana z kontemplacją, lecz idzie znacznie dalej, twierdząc, że duchowa wymowa tego pierwszego nie przekracza granic wyznaczonych przez epokę Syna, natomiast to, na co wskazuje Jan, pojawia się już w epoce Syna, ale w pełni rozwinie się w kolejnej, czyli epoce Ducha Świętego ${ }^{39}$. Jak łatwo zauważyć, Joachimowa wizja stawia pod znakiem zapytania dalsze istnienie kościelnej hierarchii w epoce Ducha Świętego. Kiedy kilkadziesiąt lat po śmierci opata Kościół zmagał się z radykalną eschatologią franciszkańskiego teologa Gerarda z Borgo San Donnino, członkowie papieskiej komisji, powołanej do zbadania zawartości jego pism i inspirujących franciszkanina dzieł Joachima z Fiore, natychmiast zauważyli ten niezwykle delikatny problem. Papiescy teologowie, zebrani w podrzymskim Anagni, stwierdzili wprost, że Joachim z Fiore zapowiada w przyszłości zmniejszenie roli duchownych w Kościele, aż do ich całkowitego zaniku (depressio ordinis clericalis et cessatio ejusdem) ${ }^{40}$.

operis perseverantia est, et voce Veritatis dicitur: «Qui autem perseveraverit usque in finem, hic salvus erit» (Mt 10, 22; 24, 13)".

${ }^{37}$ Ioachim abbas Florensis, Quaestio de Maria Magdalena et Maria sorore Lazari et Marthae II 2, ed. Patschovsky - Potestà, s. 253-254, tłum. własne.

${ }^{38}$ Więcej na ten temat zob. Grzeszczak, Joachim z Fiore, s. 81-90.

${ }^{39}$ Por. Ioachim abbas Florensis, Expositio in Apocalypsim, Liber introductorius 19, Venetiis 1527 [reprint: Frankfurt a.M. 1964], f. 17b-19a.

${ }^{40}$ Por. Protocoll der Commission zu Anagni, w: H. Denifle, Das Evangelium aeternum und die Commission zu Anagni, „Archiv für Literatur und Kirchengeschichte des Mittelalters” 1 (1885) 115 i 118; J.I. Saranyana, Joaquin de Fiore y Tomas de Aquino. Historia doctrinal de una polemica. Con la colaboracion de: Ignacio Brosa y Francesco Calogero, Pamplona 1979, 57-86; Grzeszczak, Chwila jest bliska, s. 152-154 i 159-165. 
Wracając do postawionego wyżej pytania o to, czy Maria, siostra Marty, jest kobietą z Ewangelii według św. Mateusza, która wylała Jezusowi na głowę olejek podczas uczty u Szymona Trędowatego, należy zauważyć, że opat z Fiore nie ma co do tego żadnych watpliwości, ponieważ - jak twierdzi - przemawiają za tym zarówno miejsce jak i czas tego ewangelicznego epizodu $^{41}$. Po przywołaniu zbieżnych fragmentów Jana i Mateusza o uczcie w Betanii (por. J 12, 1-8; Mt 26, 8-12), Joachim konkluduje:

„Tak więc zarówno nazwa miejscowości, jak i sam gest namaszczenia oraz słowa Pana, prowadzą do stwierdzenia, że przez kobietę tę należy rozumieć świętą Marię, siostrę Marty"42.

2. Przesłanie ewangelicznych epizodów. Przejdźmy teraz do drugiej, kluczowej części tego artykułu. Porównanie gestu namaszczenia w Betanii w przekazie Ewangelistów Mateusza i Marka z opisem Janowym prowadzi do oczywistego stwierdzenia, że dwaj synoptycy wspominają o głowie Jezusa, natomiast Jan o stopach (por. Mt 26, 7; Mk 14, 3; J 12, 3). Jeśli przyjmiemy, że gestu tego dokonała ta sama osoba, a była nią Maria z Betanii, pojawia się $\mathrm{w}$ tym momencie istotny problem interpretacyjny. Sam Joachim uważa, że stanął przed poważnym wyzwaniem (questio difficillima), które jednak podjął, uciekając się do przywołanej wyżej metody skrypturystycznej ${ }^{43}$.

Gest namaszczenia stóp Jezusa w Betanii przywodzi na myśl wzruszającą scenę z Galilei w domu faryzeusza w Ewangelii według św. Łukasza. Tym, co łączy obydwa namaszczenia stóp Jezusa, jest osoba gospodarza uczty, a konkretnie jego imię - Szymon, choć ten z Galilei był faryzeuszem, a ten z Betanii nosił przydomek „Trędowaty”. Joachim twierdzi, że to właśnie tutaj należy szukać wytłumaczenia dla opinii przywołanych wyżej Ojców Kościoła, które prowadziłyby do postawienia znaku równości pomiędzy grzesznicą z Nain i Marią z Betanii. Ostatecznie więc wnioski, jakie sugerowałaby argumentacja Ojców, można by streścić następująco: jeżeli grzesznica z Galilei jest Marią Magdaleną, a Maria Magdalena jest Marią z Betanii, to grzesznica z Galilei jest Marią z Betanii, zwłaszcza że to właśnie te dwie ostatnie namaściły stopy Jezusa. Joachim jednak zdecydowanie odrzuca tego typu wnioskowania ${ }^{44}$.

${ }^{41}$ Por. Ioachim abbas Florensis, Quaestio de Maria Magdalena et Maria sorore Lazari et Marthae II 2, ed. Patschovsky - Potestà, s. 254: „Quod autem Maria soror Marthe fuerit illa mulier, que fracto alabastro uncxit caput Iesu, testantur locus et tempus".

${ }^{42}$ Tamże, ed. Patschovsky - Potestà, s. 255, tłum. własne.

${ }^{43}$ Por. tamże II 3, ed. Patschovsky - Potestà, s. 256: „De modo autem unctionis questio difficillima perseverat, quia non dicit Iohannes mulierem istam, quam dicimus esse Mariam sororem Marthe, uncxisse caput Domini, sicut dicunt Matheus et Marcus, sed pedes, ut, quod dicit Lucas de peccatrice, hoc videatur Iohannes intimare de virgine".

${ }^{44}$ Por. tamże, ed. Patschovsky - Potestà, s. 257: „Verumtamen, quia Iohannes hanc ipsam mulierem, que erat in Bethania, pedes uncxisse asserit et non caput, quod Lucas factum docet in Galilea 
Warto zauważyć, że św. Ambroży w komentarzu do Ewangelii według św. Łukasza przypomina, że niektóre fragmenty Ewangelii mogą sprawiać wrażenie, że ewangeliści różnią się w tym, co dotyczy wiary ${ }^{45}$. Autor ma na myśli gest kobiety podczas uczty u Szymona Trędowatego zestawiony z gestem grzesznicy u faryzeusza Szymona w Ewangelii Łukaszowej. Dla biskupa Mediolanu w spojrzeniu na Pismo Święte liczy się przede wszystkim duchowy wzrost człowieka, jego przejście od grzechu do sprawiedliwości, które zawdzięczamy Chrystusowi, natomiast na dalszy plan schodzą inne sprawy, w tym również pytanie o konkretne osoby ${ }^{46}$. Mamy tu do czynienia z tajemnicą wiary, a więc Bożym działaniem, które przemienia człowieka i wyprowadza go z grzechu ku sprawiedliwości. W sytuacji grzechu powinniśmy zwracać się do Chrystusa na wzór grzesznicy z Galilei i nie dotykać Jego głowy, ponieważ dopiero usprawiedliwiony ma do niej dostęp.

Joachim z Fiore najwyraźniej zna ukazaną wyżej myśl św. Ambrożego i podąża jej tropem. Interesuje go refleksja nad tajemnicami wiary, o czym świadczy użyte po raz kolejny wyrażenie causa misterii, które już po raz drugi kieruje naszą uwagę na główne elementy Joachimowej wizji dziejów, zwłaszcza w jej wymiarze moralnym ${ }^{47}$. Kalabryjski opat jest wyrazicielem dotychczasowej tradycji egzegetycznej, choć wprowadza do niej własne rozwiązania, które nie mają wcześniejszych odpowiedników. Jednym z takich rozwiązań jest stwierdzenie, że kobieta, która nie jest grzesznica, powinna zarówno namaścić Jezusowi głowę, do czego ma prawo z racji swojej sprawiedliwości, jak i pokornie przypaść Mu do stóp ${ }^{48}$. To, że grzesznica nie powinna sięgać do głowy Chrystusa, nie oznacza bynajmniej, że sprawiedliwa nie powinna sięgać do Jego stóp, ponieważ - jak twierdzi Joachim -

„czym innym jest postawa pokory w sprawiedliwości, a czym innym zlekceważenie w grzechu tego, co wyższe" ${ }^{" 49}$.

per mulierem peccatricem, accidit, ut nonnulli unam eandemque fiusse putarent et indifferenter unam pro altera scriptitarent, sicut pro Simone illo phariseo Simonem qui vocatur leprosus. Non est autem sic, sed sicut debet intelligi, ita est".

${ }^{45}$ Por. Ambrosius Mediolanensis, Expositio Evangelii secundum Lucam 6, 12, PL 15, 1671: „Hoc loco [Łk 7, 37 - J.G.] plerique pati videntur scrupulum, et serere quaestiones, utrumnam videantur Evangelistae duo discordasse de fide; an vero aliquam in dictorum diversitate diversitatem signare voluisse mysterii".

${ }^{46}$ Por. nota 19.

${ }^{47}$ Por. nota 37.

${ }^{48}$ Por. Ioachim abbas Florensis, Quaestio de Maria Magdalena et Maria sorore Lazari et Marthae II 3, ed. Patschovsky - Potestà, s. 258: „Non enim debuit iusta mulier solum sanctum Domini contingere caput, ne superbe pedes Domini contempnere videretur". A. Patschovsky zauważa, że element ten jest typowo Joachimowy i nie można znaleźć dla niego żadnego odpowiednika w dotychczasowej tradycji. Por. tamże, nota 93.

49 Tamże: ,aliud est in iustitia humilitatem amplecti, aliud in peccato non tenere sublimia”, tłum. własne. 
Zachętę do takiego postępowania znajdziemy - zdaniem Joachima - w samej Ewangelii:

„Jeśli cię kto zaprosi na ucztę, nie zajmuj pierwszego miejsca [...] lecz gdy będziesz zaproszony, idź i usiądź na ostatnim miejscu" (Łk 14, 8. 10) $)^{50}$.

W podobnym tonie wypowiada się mędrzec Syrach: „O ile wielki jesteś, o tyle się uniżaj, a znajdziesz łaskę u Pana" (Syr 3, 18).

W myśli Joachima z Fiore pokora jawi się jako logiczna konsekwencja bycia grzesznikiem i jest jedyną postawą jakiej się od niego wymaga: „Jedno więc wystarczy grzesznikowi: żyć w pokorze, natomiast sprawiedliwy potrzebuje jednego i drugiego"51. Rozważania opata mają za konkluzję piękną sentencję:

„Nie wszystkie [...] pokorne zbawione są dziewicami, lecz wszystkie zbawione dziewice są pokorne - w przeciwnym razie nie dostępują zbawienia" ${ }^{52}$.

Tak więc grzesznikowi pozostaje pokora, natomiast sprawiedliwemu pokora i dziewictwo ${ }^{53}$.

Po tych uwagach ogólnych, odzwierciedlających jego spojrzenie na pokorę, kalabryjski opat wraca do otwartych kwestii z Ewangelii. Pokorni obejmują stopy Jezusa, natomiast pokorne dziewice oprócz stóp namaszczają też Jego głowę, ponieważ - jako sprawiedliwe - mają do tego prawo. Przykładem tej pierwszej postawy jest grzesznica z Łukaszowej Ewangelii. Można by się spodziewać, że sprawiedliwa, pobożna i umiłowana przez Jezusa Maria z Betanii, zamiast namaszczać Mu nogi i ocierać je swoimi włosami, namaści Mu głowę, co zresztą ma miejsce u Mateusza i Marka. Inaczej jest u Jana: „Maria zaś wzięła funt szlachetnego i drogocennego olejku nardowego i namaściła Jezusowi nogi, a włosami swymi je otarła" $(\mathrm{J} 12,3)^{54}$. Skąd się biorą te różnice? Joachim thumaczy je jednym zdaniem:

${ }^{50}$ Tamże, tłum. własne.

${ }^{51}$ Tamże, tłum. własne.

${ }^{52}$ Tamże: „Non enim omnes humiles qui salvantur virgines sunt, sunt autem omnes virgines qui salvantur humiles, alioquin non salvantur", thum. własne.

${ }^{53}$ Por. tamże: „Ergo habent illi solam humilitatem, isti humilitatem et virginitatem”.

${ }^{54}$ Por. tamże: „Quocirca illi vadunt ad pedes, quia tantum humiles sunt; isti, quia humiles ad pedes, quia virgines ad caput. Digni sunt enim, quia contingant utrumque. Hec ergo causa est, cur illa mulier, que erat in civitate peccatrix, ad pedes tantum accessisse describitur; que iam iusta erat et amabatur a Iesu apud Iohannem dicitur accessisse ad pedes, apud Matheum et Marcum ad caput: ad alterum quia ancilla, ad alterum quia in Domino libera". W liście do Galatów 4, 21-31 św. Paweł wyjaśnia alegoryczne znaczenie Hagar i Sary jako figur dwóch Przymierzy. Joachim z Fiore włącza je do swojej bogatej hermeneutyki tekstów biblijnych. Paralelizm zachodzący pomiędzy służebnicą i wolną oraz kobietą zamężną i poświęconą Bogu dziewicą pojawia się też w piątej księdze jego Zgodności Starego i Nowego Testamentu. Zob. Ioachim abbas Florensis, Concordia Novi ac Veteris Testamenti, hrsg. A. Patschovsky, t. 3, MGH, Quellen zur Geistesgeschichte des Mittelalters 28, Wiesbaden 2017, 507: „cum videmus aliquam virginem dicatam Deo, et dicimus: «Hec libera est!», videmus coniugatam et dicimus: «Hec ancilla!»". Na temat roli Hagar i Sary w Joachimowej hermeneutyce zob. Grzeszczak, Joachim z Fiore, s. 85, 87-88, 96, 119, 168 i 175. 
„Tak jak u dziewiczego Jana nie ma chęci przywłaszczenia sobie czegokolwiek dla siebie czy sobie podobnych, tak też u Mateusza, niegdyś celnika, nie ma zamiaru pominięcia milczeniem doskonałości świętej kobiety" ${ }^{55}$.

Quaestio de Maria Magdalena et Maria sorore Lazari et Marthae nie została skierowana do żadnego konkretnego adresata. Poza kodeksem z Padwy nie zachował się żaden inny średniowieczny rękopis tekstu. Nie można wykluczyć, że przyczyną tego stanu rzeczy była sława Joachima z Fiore jako myśliciela niekonwencjonalnego i kontrowersyjnego ${ }^{56}$. Dopiero w ostatnich dziesięcioleciach, na fali wzmożonego zainteresowania Joachimową spuścizną, pojawiły się kolejne edycje traktatu, który A. Patschovsky określa mianem „małego arcydzieła” (ein kleines Kabinettsstück) ${ }^{57}$. Quaestio wpisuje się w ciąg niewielkich objętościowo rozpraw kalabryjskiego opata, osadzonych zwykle w kontekście monastycznym lub związanych z bieżącymi wydarzeniami.

W przeanalizowanym traktacie Joachim z Fiore, bardziej niż apokaliptyczny wizjoner, jawi się jako nauczyciel i wychowawca mnichów, choć zastosowaną przez niego metodę skrypturystyczną znaleźć można również w innych mniejszych dziełach jego autorstwa, a jej oryginalnym rozwinięciem jest Joachimowa ,zgodność” (concordia) Starego i Nowego Testamentu. Oryginalne spojrzenie na ewangeliczne epizody z udziałem kobiet stanowi jednocześnie średniowieczny przykład dialogu z egzegezą Ojców i ma na celu zwrócenie uwagi na kluczową rolę cnoty pokory w ówczesnej formacji zakonnej. Cnota ta jest dla Joachima nie tylko wymogiem o charakterze indywidualnym, lecz odgrywa także decydującą rolę w zrozumieniu dziejowych procesów. Do tych ostatnich należy widoczny na przestrzeni dziejów rozwój życia kontemplacyjnego (vita contemplativa), którego finałem jest nadejście zapowiadanego przez kalabryjskiego opata tertius status, czyli epoki Ducha Świętego. Jak jednak mieliśmy okazję zauważyć wyżej, sama kontemplacja domaga się pokory, a przykład ich pięknej symbiozy możemy - mając za przewodnika Joachima z Fiore - znaleźć wprost w Ewangelii, która stawia nam przed oczyma piękne, a jednocześnie wymowne postacie kobiet dotkniętych przemieniającą łaską Boga.

${ }^{55}$ Ioachim abbas Florensis, Quaestio de Maria Magdalena et Maria sorore Lazari et Marthae II 3, ed. Patschovsky - Potestà, s. 258-259: „Et illud apud Iohannem, qui virgo fuit, ne sibi velut e simili arrogare aliquid videretur, istud apud Matheum, qui aliquando publicanus, ne excellentiam sancte mulieris preterire silentio videretur", tłum. własne.

${ }^{56}$ Por. Patschovsky, Einleitung, s. 236-237.

${ }^{57}$ Por. tamże, s. 221. 
THE MORAL SIGNIFIANCE OF THE GESTURE OF ANOINTING JESUS' FEET AND HEAD IN JOACHIM OF FIORE'S QUAESTIO DE MARIA MAGDALENA ET MARIA SORORE LAZARI ET MARTHAE

\section{(Summary)}

Joachim of Fiore (1135-1202) - a Middle Age exegete and mystic - is the author of an impressive work on the vision of history, whose most renown element is the tertius status, i.e. the age of the Holy Spirit which precedes the end of the world and the Final Judgment. As an author, Joachim was also interested in the history of religious life in the Middle Ages and in various exegetical tools which he developed to analyze this subject. In his works, especially the minor ones, he also discusses practical problems related to religious life in the $12^{\text {th }}$ century.

The small tractate, Questio de Maria Magdalena et Maria sorore Lazari et Marthae, has been preserved in a single $13^{\text {th }}$ century manuscript and is kept in the Biblioteca Antoniana in Padua. In his exegesis on various Gospel passages which deal with the anointing of Jesus' feet and head in Galilee and Bethany, Joachim of Fiore intends to show that the actions of women who performed this gesture possess a hidden moral significance: the certainty concerning the internal unity that occurs between contemplation and the virtue of humility. An example of this unity is Mary of Bethany who anointed the feet of Jesus and wiped them with her hair (cf. Jn 12:3) as a person who is humble and - at the same time - given to contemplation. Still - according to Joachim - as a righteous person, she had the right to reach for the head of the Savior.

Key words: women in the Gospel, Joachim of Fiore, humility.

Słowa kluczowe: kobiety w Ewangelii, Joachim z Fiore, pokora.

\section{BIBLIOGRAFIA}

\section{Źródła}

Ambrosius Mediolanensis, Expositio Evangelii secundum Lucam libris X comprehensa, PL 15, 1527-1850.

Epistola Clementis III. papae ad Ioachimum abbatem de Curatio, ed. A. Patschovsky - G.L. Potestà, w: Ioachim abbas Florensis, Scripta breviora, Fonti per la storia dell'Italia medievale, Antiquitates 40, Roma 2014, 471-474.

Gregorius Magnus, Dialogi, I-III, éd. A. De Vogüé, SCh 260, Paris 1979, tłum. E. Czerny - A. Świderkówna, w: Św. Grzegorz Wielki, Dialogi, ŹM 23, Kraków 2007 - Tyniec, 85-286.

Gregorius Magnus, XL homiliarum in Evangelia libri duo, PL 76, 1075-1312.

Ioachim Abbas Florensis, Concordia Novi ac Veteris Testamenti, hrsg. A. Patschovsky, MGH, Quellen zur Geistesgeschichte des Mittelalters 28, t. 2-3, Wiesbaden 2017, tłum. P. Grad: Joachim z Fiore, Księga zgodności Starego i Nowego Testamentu (fragmenty), „Kronos. Metafizyka, kultura, religia” 29 (2014) nr 2, 36-41. 
IoAchim abBas Florensis, De articulis fidei ad fratrem Iohannem. Confessio fidei, ed. V. De Fraja, Fonti per la storia dell'Italia medievale, Antiquitates 37, Roma 2012, 1-61.

Ionchim abBas Florensis, De prophetia ignota, ed. A. Patschovsky - G.L. Potestà, w: tenże, Scripta breviora, Fonti per la storia dell'Italia medievale, Antiquitates 40, Roma 2014, 55-90; Gioacchino da Fiore, Commento a una profezia ignota, a cura di M. Kaup, Opere di Gioacchino da Fiore: testi e strumenti 10, Roma 1999, 151-181.

IoAchim abBas Florensis, De septem sigillis, w: J.E. Wannenmacher, Hermeneutik der Heilsgeschichte: De septem sigillis und die sieben Siegel im Werk Joachims von Fiore, Leiden 2005, 336-355, thum. A. Serafin: Joachim z Fiore, O siedmiu pieczęciach, „Kronos. Metafizyka, kultura, religia” 29 (2014) nr 2, 74-77.

Ionchim abbas Florensis, De ultimis tribulationibus, ed. A. Patschovsky - G.L. Potestà, w: tenże, Scripta breviora, Fonti per la storia dell'Italia medievale, Antiquitates 40, Roma 2014, 281-310.

IoAchim abBas Florensis, Epistola ad abbatem A. Veldonensis monasterii, ed. A. Patschovsky - G.L. Potestà, w: tenże, Scripta breviora, Fonti per la storia dell'Italia medievale, Antiquitates 40, Roma 2014, 325-334, tłum. M. Beściak - D. Budzanowska: Joachim z Fiore, List do Wielebnego Opata Valdony, „Kronos. Metafizyka, kultura, religia" 29 (2014) nr 2, 78-80.

Ionchim abBas Florensis, Epistola testamentaria, ed. A. Patschovsky - G.L. Potestà, w: tenże, Scripta breviora, Fonti per la storia dell'Italia medievale, Antiquitates 40, Roma 2014, 385-392.

IoAChim abBas Florensis, Epistola Universis Christi fidelibus, ed. A. Patschovsky - G.L. Potestà, w: tenże, Scripta breviora, Fonti per la storia dell'Italia medievale, Antiquitates 40, Roma 2014, 353-369, tłum. M. Beściak - D. Budzanowska: Joachim z Fiore, List do wszystkich wiernych, „Kronos. Metafizyka, kultura, religia” 29 (2014) nr 2, 81-85.

IoAChim abBas Florensis, Expositio in Apocalypsim, Venetiis 1527 [reprint: Frankfurt a.M. 1964], tłum. D. Nowakowski: Joachim z Fiore, Wykład Apokalipsy (fragmenty), „Kronos. Metafizyka, kultura, religia” 29 (2014) nr 2, 56-60.

IoACHIM ABBAs Florensis, Genealogia sanctorum antiquorum patrum, ed. A. Patschovsky - G.L. Potestà, w: tenże, Scripta breviora, Fonti per la storia dell'Italia medievale, Antiquitates 40, Roma 2014, 15-28.

IoAChim ABBAs Florensis, Hymnus de regno patriae supernae, ed. A. Patschovsky - G.L. Potestà, w: tenże, Scripta breviora, Fonti per la storia dell'Italia medievale, Antiquitates 40, Roma 2014, 453-462.

IOACHIM ABBAS FloRENSIS, Intelligentia super calathis ad abbatem Gafridum, ed. A. Patschovsky - G.L. Potestà, w: tenże, Scripta breviora, Fonti per la storia dell'Italia medievale, Antiquitates 40, Roma 2014, 183-217.

Ioachim abBas Florensis, Praefatio (Apocalypsis liber ultimus, Locuturi aliquid), ed. K.-V. Selge, w: Gioacchino da Fiore, Introduzione all'Apocalisse, Opere di Gioacchino da Fiore: testi e strumenti 6, Roma 1995, 26-45, thum. P. Grad: Joachim z Fiore, Wprowadzenie do Apokalipsy, „Kronos. Metafizyka, kultura, religia” 29 (2014) nr 2, $42-55$.

IoAchim abbas Florensis, Psalterium decem cordarum, hrsg. K.-V. Selge, MGH, Quellen zur Geistesgeschichte des Mittelalters 20, Hannover 2009, tłum. M. Beściak: Joachim z Fiore, Psalterium o dziesięciu strunach (fragmenty), „Kronos. Metafizyka, kultura, religia" 29 (2014) nr 2, 61-73.

IoAchim ABbas Florensis, Quaestio de Maria Magdalena et Maria sorore Lazari et Marthae, w: tenże, Scripta breviora, ed. A. Patschovsky - G.L. Potestà, Fonti per la storia dell'Italia medievale, Antiquitates 40, Roma 2014, 243-260. 
Ioachim abBas Florensis, Soliloquium, ed. A. Patschovsky - G.L. Potestà, w: tenże, Scripta breviora, Fonti per la storia dell'Italia medievale, Antiquitates 40, Roma 2014, 113-147.

IOACHIM ABBAS Florensis, Tractatus in expositionem vite et regule beati Benedicti cum appendice fragmenti (I) de duobus prophetis in novissimis diebus praedicaturis, ed. A. Patschovsky, Fonti per la storia dell'Italia medievale, Antiquitates 29, Roma 2008.

IoAchim abBas Florensis, Visio admirandae historiae, ed. A. Patschovsky - G.L. Potestà, w: tenże, Scripta breviora, Fonti per la storia dell'Italia medievale, Antiquitates 40, Roma 2014, 439-451.

Vita beati Joachimi abbatis, ed. S. Oliverio, „Florensia” 16-17 (2002-2003) 220-230.

\section{Opracowania}

Fraja V. De, Un'antologia gioachimita: il manoscritto 322 della Biblioteca Antoniana di Padova, SM 32 (1991) nr 1, 231-258.

Leo P. De, Gioacchino da Fiore. Aspetti inediti della vita e delle opere, Soveria Mannelli 1988.

Denifle H., Das Evangelium aeternum und die Commission zu Anagni, „Archiv für Literatur und Kirchengeschichte des Mittelalters" 1 (1885) 99-142.

FonseCa C.D., Gioacchino da Fiore tra riforma del monachesimo e attesa della fine, w: Gioacchino da Fiore tra Bernardo di Clairvaux e Innocenzo III. Atti del $5^{\circ}$ Congresso internazionale di studi gioachimiti, San Giovanni in Fiore - 16-21 settembre 1999, a cura di R. Rusconi, Opere di Gioacchino da Fiore: testi e strumenti 13, Roma 2001, 13-26.

Grundmann H., Ausgewählte Aufsätze, teil 2: Joachim von Fiore, MGH, Schriften 25/2, Stuttgart 1977.

Grundmann H., Kirchenfreiheit und Kaisermacht um 1190 in der Sicht Joachims von Fiore, „,Deutsches Archiv für Erforschung des Mittelalters” 19 (1963) 353-396.

Grundmann H., Studien über Joachim von Floris, Leipzig - Berlin 1927.

GrzeszczaK J., Chwila jest bliska. Wizje końca w literaturze profetycznej (XII-XX wiek), Poznań 2011.

GrzeszczaK J., Głos teologa w sprawach średniowiecznej polityki. Diagramy Roma i Babilonia oraz ich wymowa doktrynalna i moralna, „Kronos. Metafizyka, kultura, religia" (2014) $\mathrm{nr}$ 2, 122-140.

Grzeszczak J., Joachim z Fiore i filozofia dziejów, w: Przewodnik po filozofii średniowiecznej. Od św. Augustyna do Joachima z Fiore, red. A. Kijewska, Kraków 2012, 341-358.

GrzeszczaK J., Joachim z Fiore. Średniowieczny przyczynek do teologii dziejów, Poznań 2006.

Grzeszczak J., Późnośredniowieczne dziedzictwo Joachima z Fiore: Summula seu Breviloquium super Concordia Novi ac Veteris Testamenti, w: Deum et animam scire. Teksty filozoficzne dedykowane księdzu arcybiskupowi profesorowi Markowi Jędraszewskiemu, red. J. Grzeszczak - K. Stachewicz, Poznań 2015, 353-374.

Grzeszczak J., Two Diagrams Rome and Babylon and Their Doctrinal and Moral Message, „Annali di scienze religiose” 5 (2012) 141-170.

Kaup M., Introduzione, w: Gioacchino da Fiore, Commento a una profezia ignota, a cura di M. Kaup, Opere di Gioacchino da Fiore: testi e strumenti 10, Roma 1999, 7-143.

McGinn B., The Calabrian Abbot. Joachim of Fiore in the History of Western Thought, New York 1985.

Patschovsky A., Quaestio de Maria Magdalena - Einleitung, w: Ioachim abbas Florensis, Scripta breviora, ed. A. Patschovsky - G.L. Potestà, Fonti per la storia dell'Italia medievale, Antiquitates 40, Roma 2014, 221-242.

Potestà G.L., Il tempo dell'Apocalisse. Vita di Gioacchino da Fiore, Bari 2004. 
Reeves M., The Influence of Prophecy in the Later Middle Ages. A Study in Joachimism, Notre Dame - London 1993.

Saranyana J.I., Joaquin de Fiore y Tomas de Aquino. Historia doctrinal de una polemica. Con la colaboracion de: Ignacio Brosa y Francesco Calogero, Pamplona 1979.

Szyмik S., Maria Magdalena, EK XI 1319-1320.

Western Mediterranean Prophecy. The School of Joachim of Fiore and the Fourteenth-Century Breviloquium, ed. H. Lee - M. Reeves - G. Silano, Toronto 1989.

Zвiciak J., Joachim z Fiore, EK VIII 28-29. 
